\title{
ASSOCIATIONS OF KNOWLEDGE AND ATTITUDE WITH PAP SMEAR TEST UTILIZATION
}

\author{
Meidona Nurul Milla'), Yulice Soraya Nur Intan²) \\ 1)Department of Anatomy, Faculty of Medicine, Universitas Islam Sultan Agung \\ 2)Department of Obstetrics and Gynecology, Faculty of Medicine, \\ Universitas Islam Sultan Agung
}

\begin{abstract}
Background: Cervical cancer is the second leading cause of cancer deaths for women globally, with an estimated $88 \%$ of deaths occurring in the developing world. Pap smear, also called a Pap test, is a procedure to test for cervical cancer in women involving collection of cervical cells specimen for microscopic examination. Detecting cervical cancer early with a Pap smear gives a greater chance at a cure. It can also detect changes in cervical cells that suggest cancer that may develop in the future. Detecting these abnormal cells early is a first step in halting the possible development of cervical cancer. This study aimed to analyze the associations of knowledge and attitude with the use of pap smear test.

Subjects and Method: This was a cross sectional study conducted at Kraton Hospital, Pekalongan, Central Java. A sample of 323 women of reproductive age was selected for this study, consisting of women who used Pap smear and those who did not use Pap smear. The dependent variable was Pap smear utilization. The independent variables were knowledge and attitude toward cervical cancer and its screening. Pap smear data were obtained from the medical record. The other data were collected by questionnaire. The data were analyzed by a multiple logistic regression.
\end{abstract}

Results: Knowledge $(\mathrm{OR}=2.35 ; \mathrm{p}=0.001)$ and favorable attitude toward cervical cancer and its screening $(\mathrm{OR}=3.17 ; \mathrm{p}=0.023)$ were associated with Pap smear utilization.

Conclusion: Use of Pap smear is affected by knowledge and attitude toward cervical cancer and its screening.

Keywords: knowledge, attitude, Pap smear test, cervical cancer

\section{Correspondence:}

Meidona Nurul Milla. Department of Anatomy, Faculty of Medicine, Universitas Islam Sultan Agung, Semarang, Central Java. Email: meidonamilla@yahoo.co.id. Mobile: 081225834344 . 